\title{
Metacognitive writing strategies for vocational high school students
}

\author{
Imas Masyithoh ${ }^{1}$, Eko Suhartoyo $^{2}$ \\ 1,2English Education Department, Universitas Islam Malang, Indonesia \\ 121701073116@unisma.ac.id, 2suhartoyoeko@unisma.ac.id \\ *) correspondence: 21701073116@unisma.ac.id
}

\begin{abstract}
English writing task for students is considered as the most complex task since they need to combine all English skills on writing construction. Metacognition, the highest order thinking, has to be in writing strategies (planning, monitoring, evaluating). The students who use their metacognition can know which effective writing strategies on doing their writing task. This research aimed to elaborate on whether there are significant differences between high and low achievers in writing using metacognitive strategies or not. The researcher selected the Ex-Post Facto research and emerged two instruments; (1) writing test - descriptive text to differentiate between high and low achievers in writing (2) questionnaire - to identify the most and the least uses of metacognitive writing strategies. With the Independent T-test for analyzing the data, the findings are; (1) The uses of metacognitive writing strategies and students' writing performance are not significantly different. The mean of each strategy had been compared to the mean of students' performance; moreover, based on the statistical analysis at SPSS, it showed no significant difference. (2)The most frequently used strategy by high and low achievers in writing is planning while the least is monitoring. From these findings, the null hypothesis is accepted. Although there were no significant differences in the uses of metacognitive writing strategies between high and low achievers in writing; The students have already known what effective writing strategies to improve their writing.
\end{abstract}

Keywords: metacognition; metacognitive writing strategies; students' performance; writing

\section{INTRODUCTION}

Considering that English is in subject-categorized in Permendikbud No 37 2018; however National Examination has been excluded for higher school's graduation, English still needs to deepen in term of preparations (Yunardi, 2014). Since those examinations call English as complex and structured in limited time test, learning writing is good to be students' 'on focus.' Aside from understanding students' English proficiency level, figuring out their way of facing the subject then following their perceptions in conducting the lesson is the right choice. One step in doing this is the teacher would examine students' metacognitive writing strategies for seeing what they are in prefer to, the way class running, and writing strategies that they have already used, not mention to those that they have not used.

Metacognitive writing strategies, in short, is one of the writing strategies that has been proved by numerous researchers in their significant effect on learning English (Binandeh et al, 2017). This finding had university students as participants, thus the present research was genuinely conducted to examine if metacognitive writing strategies also contributed on vocational high school students' writing achievements. Mohite's (2014) research revealed the most and less use of writing strategies in English by Polish senior high school students. Evaluating is in the first place, then monitoring and planning, and they are metacognitive writing strategies used by the participants. Yet, the instrument questionnaire was broadly in three categories; social, cognitive, and metacognitive. Further research should be demanded better findings while investigating one of the categories as consideration. Then, the roles of high and low achievers in writing were to seek the differences of their use in metacognitive strategies by Wang and Han (2017). They asserted that writing achievements do not contribute any differences in students' uses of metacognitive strategies. Whereas, Farahian and Avarzamani's (2018) finding was not in line with Wang and Han's. They declared that writing achievements give significant 
roles in using metacognitive strategies. Regarding the exact opposite of both findings and the different background knowledge of participants - Chinese university students, and Iranian university students, respectively, the most recent research should be eagerly conducted.

Therefore, the present research is to investigate whether there are significant differences between high and low achievers in writing using metacognitive strategies or not. In addition, it is also to discover the most and the least used of metacognitive writing strategies by high and low achievers in writing.

\section{METHODS}

This study applied an Ex-Post Facto research design and addressed a quantitative approach in form of a questionnaire. That is the initial aim that through a questionnaire, research might have a broader sample - participants in the reason of time efficiency and work. Participants who covered up the population and sample in this research were 14 students of Grade 10 in SMK Darul Ulum Purwodadi. In this quantitative research, the researcher adapted two questionnaires for identifying metacognitive writing strategies used by students. They were English Language Writing Strategies (ELWS) from a master dissertation of Miroslawa Mohite (Mohite, 2014) and Metacognitive Strategies of Writing Survey (MSWS) used in the research by Moqbali, Humaidi, and Hilal (2020). To examine which are high and low achievers in writing, the writing test also be used. The researcher chose the descriptive text for the writing test since the students have learned it. All data gathering was in one week. Subsequently, the researcher analyzed the data in IBM SPSS with the independent t-test.

\section{RESULTS AND DISCUSSION}

Writing test score was for dividing participants into high and low achievers in writing. The scores consisted of knowledge score and skill score. The mean of students' scores on both categories is the minimum completeness on descriptive text assignments (80.7). The students who have a higher score than 80.7 are considered as high achievers in writing, and the students who have a lower score than 80.7 are considered as low achievers in writing. Thus, nine students are categorized as high achievers in writing, and five students are categorized as low achievers in writing. Then, both categories were compared to their use of metacognitive writing strategies (planning, monitoring and evaluating) to figure out if they were significantly different or not.

TABLE 1. Independent T-test for Planning Strategy on Metacognitive Writing Strategies

\begin{tabular}{cccc}
\hline & High & Low \\
\hline Planning & $\mathrm{N}$ & 9 & 5 \\
$\mathrm{X}$ & 34.67 & 30.60 \\
$\mathrm{~s}$ & 7.211 & 6.066 \\
$\mathrm{t}$ & 1.064 & 1.122 \\
& Sig. (2-tailed) & .308 & .289 \\
\hline
\end{tabular}

Significant value level at the 0.05 level (2-tailed)

Based on Table 1, the data showed that the mean of the use of planning strategy on metacognitive writing strategies for high achievers in writing is 34.67 and for low achievers in writing is 30.60. With the standard deviation -7.211 and 6.066 for high and low achievers in writing, respectively, the t value is 1.064 , and the sig value is .308. Since sig value (.308) is higher than sig level at 0.05 level, the use of planning strategy on metacognitive writing strategies and students' writing achievements are not significantly different.

TABLE 2. Independent T-test for Monitoring Strategy on Metacognitive Writing Strategies

\begin{tabular}{cccc}
\hline & & High & Low \\
\hline Monitoring & $\mathrm{N}$ & 9 & 5 \\
$\mathrm{X}$ & 25 & 22.4 \\
& $\mathrm{~s}$ & 3.428 & 4.037 \\
& $\mathrm{t}$ & 1.280 & 1.217 \\
& Sig. (2 tailed) & .225 & .262 \\
\hline
\end{tabular}


Significant value level at the 0.05 level (2-tailed)

According to Table 2, the mean difference between the two groups is 2.6. The standard deviation for high achievers in writing is 3.428 and 4.037 for low achievers in writing. In addition, $t$ value is 1.280 and sig $=.225$ (sig > .05). Therefore, there is no significant difference between the use of monitoring strategy of metacognitive writing strategies and students' writing achievements.

TABLE 3. Independent T-test for Evaluating Strategy on Metacognitive Writing Strategies

\begin{tabular}{cccc}
\hline & & High & Low \\
\hline Evaluating & $\mathrm{N}$ & 9 & 5 \\
$\mathrm{X}$ & 28.78 & 27.40 \\
& $\mathrm{~s}$ & 4.116 & 5.683 \\
$\mathrm{t}$ & .526 & .477 \\
& Sig. $(2$ tailed) & .609 & .649 \\
\hline
\end{tabular}

Significant value level at the 0.05 level (2-tailed)

With the mean difference between the two groups (1.38) that is presented in Table 3, the t value is .526 and followed by the significant 2 tailed value $(\mathrm{sig}=.609)$. It means that the use of evaluating strategy on metacognitive writing strategies and students' writing achievements are not significantly different.

TABLE 4. Independent T-test for Overall Metacognitive Writing Strategies

\begin{tabular}{cccc}
\hline & High & Low \\
\hline Overall & $\mathrm{N}$ & 9 & 5 \\
$\mathrm{X}$ & 88.44 & 80.44 \\
$\mathrm{~s}$ & 13.361 & 14.758 \\
$\mathrm{t}$ & 1.042 & 1.010 \\
& Sig. (2 tailed) & .318 & .343 \\
\hline
\end{tabular}

Significant value level at the 0.05 level (2-tailed)

From Table 4, the result of analyzing the data is linear with three previous components planning, monitoring and evaluating for significant value $(2$ tailed $)=.318$ is higher than significant value level at the 0.05 level (2-tailed). Thus, the overall metacognitive writing strategies and students' writing achievements do not present a significant difference. In other words, the use of metacognitive writing strategies does not contribute significantly to high and low achievers in writing.

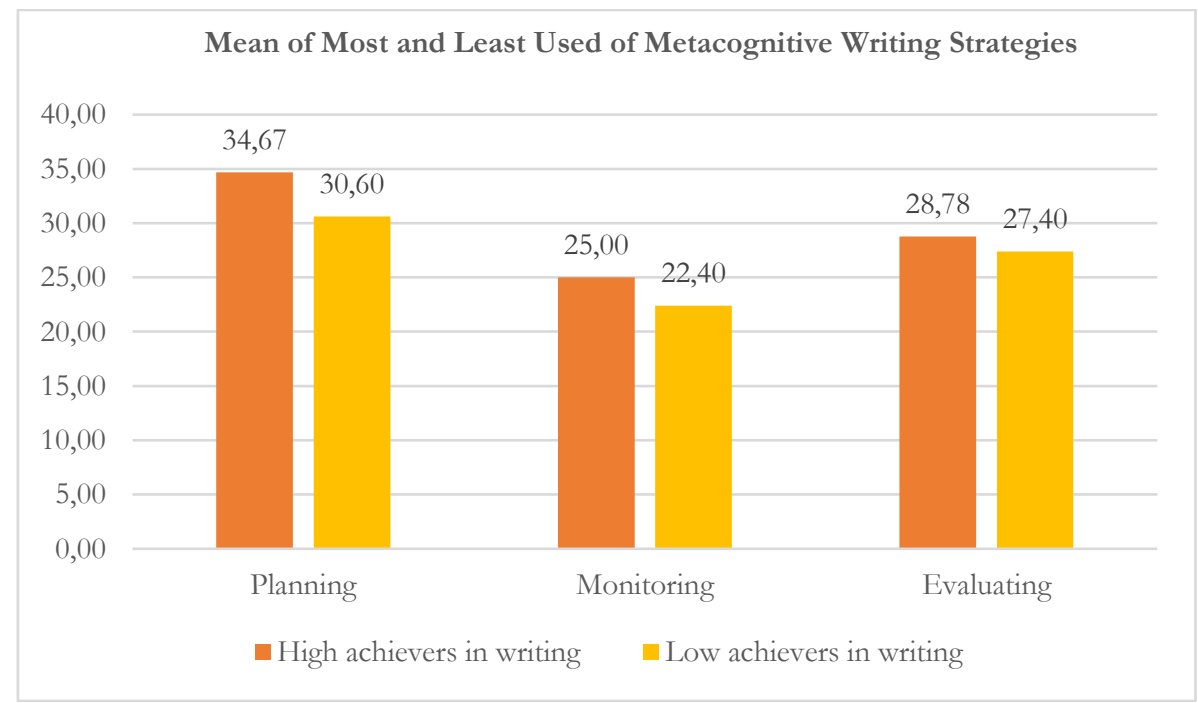

Figure 1 The Use of Metacognitive Writing Strategies

Figure 1 explained the mean of the most and the least used metacognitive writing strategies for high and low achievers in writing. It indicated that the most used metacognitive writing strategy for 
both students is planning, and the least used metacognitive writing strategy for both students is monitoring.

From the results, it made the alternative hypothesis $\left(\mathrm{H}_{\mathrm{a}}\right)$ rejected, but it accepted the null hypothesis $\left(\mathrm{H}_{0}\right)$. This research finding accorded with the research from Wang and Han (2017) that they asserted that writing achievements do not contribute any differences in their uses of metacognitive strategies. Moreover, the metacognitive awareness of secondary school students had been proven to not showing a significant difference (Jaleel \& Premachandran, 2016).

However, the use of metacognitive writing strategies by high achievers in writing was not different from the use of metacognitive writing strategies by low achievers in writing, the finding explained that planning strategy on metacognitive writing strategies was the most strategy used by both students. It implied that metacognitive writing strategies had the specific category because evaluating, one of the writing strategies - including social, cognitive and metacognitive, was the most used by Polish senior high school students (Mohite, 2014).

Planning also plays a contribution to advanced students' writing. Students who used organizedbased planning were likely to have a better argumentative essay with convincing diction than without using planning on writing construction (Limpo \& Alves, 2018). Thus, for vocational high school students, the intermediate EFL learners, planning their writing is the fruitful recommendation for exercising their writing skills because advanced writing students also still need to plan their writing.

While the results presented the most and the least used of metacognitive writing strategies as comparing the mean of each strategy and students' achievements, there are the specific percentages of students' answers in the questionnaire for per item. The most three strategies used by high and low achievers in writing were (1) I can improve my writing with error correction and the teacher's feedback (Evaluating) at $87 \%$ (2) I check to see if the language of my essay is clear (Monitoring) at $86 \%$ (3) I check if the content is relevant to the topic (Evaluating) at $84 \%$. Then, the least three strategies used by high and low achievers in writing were (1) I use study guides for English writing a lot (Planning) at 63\% (2) I read around the topic to help me in writing (Planning) at 63\% (3) I brainstorm many ideas first before I start a writing task (Planning) at 63\%.

The percentages revealed that in the results if the most and the least metacognitive writing strategies used by high and low achievers in writing were planning and monitoring, there were no certain statements that the most and the least item used by high and low achievers in writing were also planning and monitoring. The most used item was evaluating strategy and the least used item was planning strategy. It showed the variation of the questionnaire answers. It means that while they were filling up the questionnaire, they had already known the effective writing strategies for their better writing.

All in all, metacognitive writing strategies and students' writing achievements are not significantly different after the researcher analyzed the data and tested the hypotheses followed by the number of evidence for conclusions.

\section{CONCLUSION}

In brief, there were no significant differences between high and low achievers in writing in using metacognitive writing strategies. Planning was the most used metacognitive writing strategy whereas monitoring was the least used metacognitive writing strategy. As the suggestion for the English teacher referring this research, the teacher should have the self-evaluation to give more intense teaching of monitoring strategy to the students. Another possible suggestion is that the teacher can also provide the writer's self-check sheet to the students. It will help students to check their writing according to the instruction. Regarding the research method for future research, it would be good to have senior high school students as the participants since the curriculum is somewhat different from vocational high school students. Besides the sample, it would be better if two quantitative instruments used in this research are also accompanied by the qualitative instrument to represent more participants' opinions. In addition, the research with other possibilities of the independent variable might be fruitful 
for further research. One example is gender. It will be to investigate if there is a significant difference in the use of metacognitive writing strategies between male and female students.

\section{ACKNOWLEDGEMENTS}

I would particularly like to thank my first advisor, Eko Suhartoyo, S. Pd., M. Pd. who supervised me in doing this research. I would like to thank the headmaster, vice of the headmaster and the English teacher of SMK Darul Ulum Purwodadi who gave the permission and help for conducting the research there, and all Grade 10 in SMK Darul Ulum Purwodadi who shared their opinions and efforts.

\section{REFERENCES}

Binandeh, M., Rahmani, S., \& Raoofi, S. (2017). An Investigation into Writing Strategies and Writing Proficiency of University Students. Journal of Language Teaching and Research, 8(1), 191-198.

Farahian, M., \& Avarzamani, F. (2018). Metacognitive Awareness of Skilled and less-skilled EFL Writers. Asian-Pacific Journal of Second and Foreign Language Education, 3(10), 1-17.

Jaleel, S., \& Premachandran, P. (2016). A Study on the Metacognitive Awareness of Secondary School Students. Universal Journal of Educational Research, 4(1), 165-172.

Limpo, T., \& Alves, R. A. (2018). Effects of planning strategies on writing dynamics and final texts. Acta Psychologica, 188, 97-109.

Mohite, M. (2014). An Investigation into the English Language Writing Strategies Used by Polish EFL Secondary School Learners. London: British Council ELT Master's Dissertation Awards: Commendation.

Wang, Z., \& Han, F. (2017). Metacognitive Knowledge and Metacognitive Control of Writing Strategy between High- and Low-performing Chinese EFL Writers. Theory and Practice in Language Studies, 7(7), 523-532.

Yunardi. (2014). Sistem Pendidikan di Thailand. Kantor Atase Pendidikan, Kedutaan Besar Republik Indonesia (KBRI) Bangkok. 